\title{
What Could Be the Role of Antifungal Lock-Solutions? From Bench to Bedside
}

\author{
Christine Imbert ${ }^{1,2, *}$ and Blandine Rammaert ${ }^{2,3,4}$ \\ 1 Laboratory of Ecology and Biology of Interactions, University of Poitiers, UMR CNRS 7267, \\ F-86073 Poitiers, France \\ 2 Faculty of Medicine and Pharmacy, University of Poitiers, F-86073 Poitiers, France; \\ blandine.rammaert.paltrie@univ-poitiers.fr \\ 3 CHU Poitiers, Infectious and Tropical Disease Unit, F-86073 Poitiers, France \\ 4 INSERM U1070, F-86073 Poitiers, France \\ * Correspondence: christine.imbert@univ-poitiers.fr
}

Received: 28 November 2017; Accepted: 3 January 2018; Published: 6 January 2018

\begin{abstract}
Candidemia related to the presence of a biofilm are often reported in patients with vascular catheters. Once they are mature, biofilms are persistent infectious reservoirs, and the yeasts dispersed from biofilms can cause infections. Sessile yeasts typically display increased levels of resistance to most antimicrobial agents and systemic treatments usually fail to eradicate previously formed fungal biofilms. In a curative strategy, antifungal lock therapy may help to sterilize catheters, with very high concentrations of antifungal agents, which are not compatible with systemic use. This strategy has been studied by several authors in in vitro and in vivo studies, and more rarely, in clinical settings for adult and paediatric patients. Our study aims to assess the efficacy of the antifungal solutions used for lock therapy and demonstrated by the different teams.
\end{abstract}

Keywords: biofilm; antifungal agents; candidemia; catheter carrier patient

\section{Introduction}

Candida albicans belongs to human microflora and is a major opportunistic human pathogen. This species is responsible for a variety of diseases, ranging from oral thrush to candidemia, depending on patient status and fragility and/or immunosuppression level. Different factors contribute to the pathogenic potential of $C$. albicans. Although adherence ability and biofilm lifestyle are among the most important factors, we may also mention thigmotropism, yeast-to-hypha transition, secretion of hydrolases, and so on [1-3]. Adherence to an inert or living surface is the earliest phase required during the multi-step mechanism leading to formation of a biofilm. Biofilm has been defined as a structured community of microbial cells enclosed in a self-produced polymeric matrix [4]. In biofilms, sessile cells typically display increased levels of resistance to most antimicrobial agents and to host defence mechanisms, as well $[5,6]$. The ability of $C$. albicans to form biofilms associated with biotic surfaces, such as oral mucosa, and abiotic surfaces, such as implanted devices, can strongly impact human health. Importantly, biofilms are persistent infectious reservoirs of yeast cells dispersed from the biofilm that cause local and systemic infections [7]. Yeast cells dispersed from biofilms are not similar to regular planktonic yeast cells. In a recent study, Uppuluri and collaborators demonstrated that cells are likely to be dispersed primarily as yeast and that dispersion tends to occur continuously throughout biofilm development rather than being a massive event [8]. They also conclude that compared to their planktonic counterparts, dispersed cells display distinct phenotypic properties, including enhanced adherence, filamentation and pathogenicity in a murine model.

Ideally, a fully effective antimicrobial candidate treatment would kill the free microbial cells dispersed from the biofilm at the same time as the eradication of the biofilm itself. It would also be 
really advantageous if this ideal treatment totally removed the biofilm and made the catheter surface totally smooth so as to avoid or at least delay the formation of a new biofilm. It could be based on only one or a combination of molecules. In this way, the acute infection would be cured and relapse certainly delayed. Unfortunately, this ideal treatment candidate has yet to be discovered.

Candidemia are associated with reported mortality rates ranging from $30 \%$ to $60 \%$ and attributable mortality rates between $25 \%$ and $40 \%$, C. albicans being the main species involved [9-14]. Outer and inner surfaces of vascular catheters, especially long-term ones, are particularly good substrates for C. albicans biofilm development, and are consequently at high risk of biofilm-related candidemia for patients. In case of a catheter-related bloodstream infection (CRBSI) caused by Candida spp., catheter removal is currently recommended. It has been widely shown that non-removal is associated with increased mortality and more prolonged candidemia [15-24]. This recommendation has certainly been given due to the insufficient activity of currently available systemic antifungal agents against Candida spp. biofilms. Many in vitro and in vivo studies have evaluated the ability of azoles, echinocandins and amphotericin B to eradicate a previously formed biofilm. They generally showed that azoles had poor activity against $C$. albicans biofilms. On the contrary, echinocandins and lipid formulations of amphotericin B generally demonstrated higher activity, even if total eradication was not obtained. Lipid formulations of amphotericin B appeared more effective than amphotericin B deoxycholate $[5,6,9,25-29]$.

However, catheter replacement is not possible for all patients. For instance, in neonatology units extremely low birth weight infants are particularly at risk for CRBSI [30]. Candidemia occurs in approximately $10 \%$ of reported bloodstream infections in neonates [31]. The risk of CRBSI in neonatology unit has been shown to increase during the 2 weeks of catheter insertion [32]. Limited or no alternative intravenous access, particularly in children, leads to development of new approaches when catheters are infected with Candida. So, antifungal lock therapy may be helpful for these patients, in combination with conventional antifungal systemic therapy. Lock therapy involves instilling high concentrations of antimicrobial agents (usually from 100- to 1000-fold the minimal inhibitory concentration (MIC)) into the catheter lumen for extended periods of time [33,34]. This strategy is rather well-documented and defined for antiseptic and antibiotic approaches. However, the role of antifungal lock therapy against Candida is still not well-defined [15]. Biofilms may be located on both the outer and inner surfaces of vascular catheters. Of course, in case of an extra-luminal biofilm, antifungal lock would fail to eradicate biofilm.

The aim of the current article is to focus on the data available in the literature giving information about antifungal lock therapy approach in order to have better knowledge of this strategy. We will describe its efficacy and the conditions that would be the most appropriate in terms of antifungal agent, concentration, contact duration, and treatment frequency. There will be three parts successively focusing on in vitro, in vivo and clinical data. Only conventional antifungal agents will be included in this study. Many teams have developed in vitro models mimicking lock strategy to study the interest of the main available antifungal agents used as lock solutions. The main issue is the variability of the developed models that complicate comparative analysis of the results available in literature. Indeed, lock concentration, time and number of repeats, as well as biofilm substrates, maturation status of treated biofilms, and the method used to evaluate lock activity differ frequently according to the studies (Table 1). However, published results are generally in agreement and we will try below to summarize the main ideas regarding the efficacy of antifungal locks against Candida spp. biofilms. 
Table 1. Methods to evaluate the activity of antifungal lock solutions according to selected in vitro studies. $\mathrm{d}-\mathrm{AmB}=\mathrm{Amphotericin} \mathrm{B}$ deoxycholate; $\mathrm{L}-\mathrm{AmB}=$ liposomal Amphotericin B; ALT: antifungal lock treatment; XTT: 2,3-bis-(2-methoxy-4-nitro-5-sulfophenyl)-2H-tetrazolium-5-carboxanilide.

\begin{tabular}{|c|c|c|c|c|c|c|c|c|}
\hline $\begin{array}{l}\text { Candida Species and } \\
\text { Number of Strains }\end{array}$ & $\begin{array}{c}\text { Age of the } \\
\text { Treated Biofilm }\end{array}$ & Surface Nature & $\begin{array}{l}\text { Antifungal } \\
\text { Solutions }\end{array}$ & ALT Duration & $\begin{array}{c}\text { Investigation } \\
\text { of Treatment } \\
\text { Persistence }\end{array}$ & $\begin{array}{l}\text { Method for } \\
\text { Antibiofilm } \\
\text { Evaluation }\end{array}$ & Major Conclusions & Reference \\
\hline C. albicans (2) & $12 \mathrm{~h}$ and 5 days & $100 \%$ silicone & $\begin{array}{l}\text { Caspofungin; } \\
\text { micafungin }\end{array}$ & $12 \mathrm{~h}$ & $\begin{array}{l}24,48 \text { and } 72 \mathrm{~h} \\
\text { post-lock }\end{array}$ & XTT & $\begin{array}{c}48 \text { h-lock of caspofungin at } 2 \mu \mathrm{g} / \mathrm{mL} \\
\text { or micafungin at } 5 \mu \mathrm{g} / \mathrm{mL} \text { reduced } \\
\text { biofilms by } 47 \%\end{array}$ & Cateau et al., 2008 [35] \\
\hline $\begin{array}{l}\text { C. albicans (1); } \\
\text { C. glabrata (1); } \\
\text { C. tropicalis (1) }\end{array}$ & $\begin{array}{l}5 \text { days (with } \\
\text { shaking) }\end{array}$ & polyurethane & $\begin{array}{l}\text { d-AmB; } \\
\text { fluconazole; } \\
\text { itraconazole; } \\
\text { voriconazole; } \\
\text { caspofungin }\end{array}$ & $\begin{array}{c}1,3,5,7,10 \text { and } 14 \text { days } \\
\text { (lock solutions replaced } \\
\text { every } 2 \text { days) }\end{array}$ & none & $\begin{array}{c}\mathrm{XTT}+\mathrm{CFU} \\
\text { counts }\end{array}$ & $\begin{array}{c}\text { Azoles at } 1 \mathrm{mg} / \mathrm{mL} \text { eradicated all } \\
\text { biofilms within } 7 \text { to } 14 \text { days; azoles } \\
\text { were superior to d-AmB and } \\
\text { caspofungin to eradicate biofilms }\end{array}$ & Ko et al., 2010 [36] \\
\hline $\begin{array}{l}\text { C. albicans (10); } \\
\text { C. glabrata (6) }\end{array}$ & $12 \mathrm{~h}$ and 5 days & $100 \%$ silicone & $\begin{array}{l}\text { Posaconazole; } \\
\text { Caspofungin; } \\
\text { micafungin }\end{array}$ & $12 \mathrm{~h}$ & $\begin{array}{l}24,48 \text { and } 72 \mathrm{~h} \\
\text { post-lock }\end{array}$ & XTT & $\begin{array}{l}48 \text { h-lock of posaconazole reduced } \\
\text { C. albicans biofilms by }<50 \% \text { compared } \\
\text { to } \geq 60 \% \text { with echinocandins. } \\
\text { Greater sustained efficacy of } \\
\text { micafungin compared with } \\
\text { caspofungin against all biofilms of } \\
\text { C. glabrata, albeit no obvious difference } \\
\text { for C. albicans biofilms }\end{array}$ & Cateau et al., 2011 [26] \\
\hline $\begin{array}{l}\text { C. albicans }(20) ; \\
\text { C. parapsilosis }(40) ; \\
\text { C. tropicalis }(20) ; \\
\text { C. glabrata }(20) ; \\
\text { C. krusei }(20)\end{array}$ & $24 \mathrm{~h}$ & polystyrene & $\begin{array}{l}\text { d-AmB; } \\
\text { voriconazole; } \\
\text { anidulafungin; } \\
\text { caspofungin }\end{array}$ & $24 \mathrm{~h}$ & none & XTT & $\begin{array}{c}\text { inefficacy of azoles against all species } \\
\text { of } C \text {. albicans biofilms; d-AmB activity } \\
\text { was limited and strain dependent. } \\
\text { Anidulafungin more active } \\
\text { than caspofungin }\end{array}$ & Fiori et al., 2011 [37] \\
\hline $\begin{array}{l}\text { C. albicans (1); } \\
\text { C. parapsilosis (1) }\end{array}$ & 5 days & silicone & $\begin{array}{l}\text { d-AmB; } \\
\text { fluconazole; } \\
\text { itraconazole; } \\
\text { voriconazole; } \\
\text { caspofungin }\end{array}$ & $\begin{array}{c}1,3,5,7 \text { days } \\
\text { (lock solutions replaced } \\
\text { every } 2 \text { days) }\end{array}$ & none & $\begin{array}{l}\text { Determination } \\
\text { of viable count } \\
\text { (no details) }\end{array}$ & $\begin{array}{l}\text { No azole can sterilize catheters; } \\
\text { catheters treated with d-AmB or } \\
\text { caspofungin were completely sterile at } \\
\text { the fifth day }\end{array}$ & Öncü et al., 2011 [38] \\
\hline $\begin{array}{l}\text { C. albicans (2); } \\
\text { C. glabrata (2); } \\
\text { C. parapsilosis }(2)\end{array}$ & $12 \mathrm{~h}$ and 5 days & $100 \%$ silicone & L-AmB; & 4,12 and $24 \mathrm{~h}$ & 24 and $48 \mathrm{~h}$ & XTT & $\begin{array}{l}\text { High and persistent inhibitory activity } \\
\text { of L-AmB used at } 1000 \mu \mathrm{g} / \mathrm{mL} \text { for } \\
\text { short lock but no full biofilm } \\
\text { eradication; C. parapsilosis biofilm less } \\
\text { susceptible than that of other species. }\end{array}$ & Toulet et al., 2012 [27] \\
\hline $\begin{array}{c}\text { C. albicans (1); } \\
\text { C. lusitaniae (6); } \\
\text { C. guillermondii (5) }\end{array}$ & $48 \mathrm{~h}$ & polystyrene & $\begin{array}{l}\text { L-AmB; } \\
\text { anidulafungin; } \\
\text { caspofungin; } \\
\text { micafungin }\end{array}$ & $24 \mathrm{~h}$ & $\begin{array}{l}24,48 \text { and } 72 \mathrm{~h} \\
\text { post-lock }\end{array}$ & $\begin{array}{l}\mathrm{XTT}+\mathrm{CFU} \\
\text { counts }\end{array}$ & $\begin{array}{l}\text { L-AmB at } 256 \text { to } 2048 \mu \mathrm{g} / \mathrm{mL} \text { inhibited } \\
80 \text { to } 90 \% \text { of } \text { C. albicans biofilm; } \\
\text { comparable in vitro efficacy of L-AmB } \\
\text { and caspofungin against C. albicans } \\
\text { mature biofilms; anidulafungin and } \\
\text { micafungin less active than } \\
\text { caspofungin against C. albicans, } \\
\text { C. guilliermondii and C. lusitaniae. }\end{array}$ & $\begin{array}{l}\text { Simitsopoulou et al., } \\
2014 \text { [39] }\end{array}$ \\
\hline
\end{tabular}


Table 1. Cont.

\begin{tabular}{|c|c|c|c|c|c|c|c|c|}
\hline $\begin{array}{l}\text { Candida Species and } \\
\text { Number of Strains }\end{array}$ & $\begin{array}{c}\text { Age of the } \\
\text { Treated Biofilm }\end{array}$ & Surface Nature & $\begin{array}{l}\text { Antifungal } \\
\text { Solutions }\end{array}$ & ALT Duration & $\begin{array}{c}\text { Investigation } \\
\text { of Treatment } \\
\text { Persistence }\end{array}$ & $\begin{array}{l}\text { Method for } \\
\text { Antibiofilm } \\
\text { Evaluation }\end{array}$ & Major Conclusions & Reference \\
\hline C. parapsilosis (2) & $48 \mathrm{~h}$ & $\begin{array}{c}\text { silicone; } \\
\text { polystyrene }\end{array}$ & $\begin{array}{c}\text { L-AmB; } \\
\text { anidulafungin }\end{array}$ & $48 \mathrm{~h}$ & none & XTT & $\begin{array}{c}50 \% \text { biofilm reduction was obtained } \\
\text { with } 4 \text {-fold less anidulafungin } \\
(\leq 0.25 \mu \mathrm{g} / \mathrm{mL}) \text { than L-AmB } \\
(1 \mu \mathrm{g} / \mathrm{mL}) ; 90 \% \text { biofilm reduction was } \\
\text { obtained using anidulafungin at } \\
1 \mu \mathrm{mg} / \mathrm{mL} \text { compared to L-AmB at } \\
>1024 \mu \mathrm{m} / \mathrm{mL}\end{array}$ & Basas et al., 2016 [40] \\
\hline C. albicans (5) & $24 \mathrm{~h}$ & $\begin{array}{c}\text { Silicone; } \\
\text { polystyrene }\end{array}$ & micafungin & $24 \mathrm{~h}$ & none & $\begin{array}{l}\mathrm{XTT} \text { and CFU } \\
\text { counts }\end{array}$ & $\begin{array}{l}\text { High efficacy of the combination: } 20 \% \\
\text { ethanol, } 0.01565 \mu \mathrm{g} / \mathrm{mL} \text { micafungin } \\
\text { and } 800 \mathrm{~g} / \mathrm{mL} \text { doxycycline against } \\
\text { forming and mature biofilms }\end{array}$ & Lown et al., 2016 [41] \\
\hline
\end{tabular}




\section{Azole Lock Solutions}

In most instances, all available data suggested that azole lock solutions fail to eradicate preformed C. albicans biofilms, regardless of test conditions. Öncü studied the efficacy of three azole (fluconazole, itraconazole and voriconazole) locks to eradicate a mature C. albicans biofilm, 5 days old, previously formed on silicone catheters, using only one strain. Fungal eradication was evaluated by determining the viable count. The author showed that no azole sterilized catheters, with more than $10^{5} \mathrm{CFU}$ after the 7-day lock period compared to more than $10^{6} \mathrm{CFU}$ on the non-treated catheters. Very high concentrations of major azole solutions failed to eradicate biofilms despite extended lock duration ( $24 \mathrm{~h}$ each) and repetition (for 7 days) [38]. Fiori et al. also tested fluconazole and voriconazole lock solutions, and included 20 clinical strains of C. albicans in their study; biofilms were formed on polystyrene surfaces (96-well microtiter-based method) but their maturation status was unclear [37]. The lowest azole concentrations at which a $50 \%$ decrease in biofilm metabolic activity (2,3-bis-(2-methoxy-4-nitro-5-sulfophenyl)-2H-tetrazolium-5-carboxanilide [XTT] method) was observed were always $>128 \mu \mathrm{g} / \mathrm{mL}$ (fluconazole and voriconazole), confirming their inefficiency against $C$. albicans biofilms [37]. These lock solutions were also tested against numerous C. non-albicans biofilms (C. glabrata, C. parapsilosis, C. tropicalis and C. krusei). Again, the minimal concentrations reducing biofilms by half always exceeded $>128 \mu \mathrm{g} / \mathrm{mL}$ [37]. Our team evaluated the efficacy of posaconazole lock solutions to eradicate $12 \mathrm{~h}$-young and 5-day-old mature biofilms of C. albicans previously formed on silicone catheters. In this study posaconazole was tested at $10 \mathrm{mg} / \mathrm{L}$ corresponding to concentrations approximately 100-200 MIC and 16 strains of Candida sp. (ten of C. albicans and six of C. glabrata) were studied [26]. Posaconazole induced C. albicans biofilm inhibition ranging from $54.2 \%$ (young biofilms) to $57.6 \%$ (mature) $24 \mathrm{~h}$ after lock solution removal. Inhibition persisted over a $48 \mathrm{~h}$ post-lock period (inhibition ranging from $49.7 \%$ to $48.4 \%$ respectively). In this study posaconazole halved C. albicans biofilms regardless of their maturity level with a persistent effect. However, under the same test conditions posaconazole did not inhibit C. glabrata biofilms [26]. These results concurred with those reported by other teams who obtained no more than $40 \%$ inhibition of C. albicans biofilm tested at different maturation phases ( $24 \mathrm{~h}$ to $72 \mathrm{~h}$-old biofilms) $[42,43]$. In their study Katragkou et al. tested voriconazole and posaconazole concentrations up to $256 \mu \mathrm{g} / \mathrm{mL}$ and prepared biofilms on silicone elastomer surfaces [43]. Their results showed that these highly concentrated lock solutions were not able to reduce $72 \mathrm{~h}$-old C. parapsilosis biofilm metabolic activity by more than about $60 \%$ (voriconazole) or $40 \%$ (posaconazole). Only one study gave divergent results showing that fluconazole, itraconazole, and voriconazole at concentrations of $1 \mathrm{mg} / \mathrm{mL}$ eliminated detectable viability in biofilms (5-day-old) made by C. albicans, C. glabrata and C. tropicalis within 7, 10 and 14 days on polyurethane surfaces, respectively [36]. In this treatment, lock solutions were replaced every 2 days. Fourteen days is a very long time and tested lock periods are usually shorter, which may help to explain the divergent data. In addition, these results may be strain-dependant as authors studied only one strain of each species of Candida. To our knowledge, this study from Ko et al. is the only one demonstrating that itraconazole, fluconazole, and voriconazole are generally superior to caspofungin and amphotericin B [36].

Finally, in vitro literature data primarily underscores the inability of available azoles, such as fluconazole, itraconazole, voriconazole and posaconazole to reduce the metabolic activity in C. albicans biofilms by more than half, regardless of the tested biofilm maturation status, azole concentration and contact duration. Given the failure of in vitro data, no clinical data exist on azole lock. One in vivo study using a rabbit model of $C$. albicans CRBSI was consistent with in vitro models. This study assessed the efficacy of liposomal amphotericin B (L-AmB) compared to fluconazole lock-therapies [44]. The antifungal solutions were locked in the lumen of each catheter for $8 \mathrm{~h}$ per day for 7 days. L-AmB was more efficient in catheter sterilization than fluconazole. 


\section{Amphotericin B Lock Solutions}

Available data regarding the efficacy of antifungal lock solutions based on amphotericin $B$ deoxycholate (d-AmB), and lipid formulations of amphotericin B, such as amphotericin B lipid complex (ABLC) and L-AmB will be reported in this part. Öncü evaluated in vitro the capacity of amphotericin B lock solutions ( $36 \mu \mathrm{g} / \mathrm{mL}$ to $120 \mu \mathrm{g} / \mathrm{mL}$ ) to eradicate mature (5-day old) biofilms formed on silicone catheters using a viability approach (CFU method) as previously mentioned for azole testing [38]. Results showed that d-AmB significantly decreased the number of yeasts inside catheters, which were completely sterile at the fifth day. Furthermore, d-AmB efficiency was observed as early as the first day whatever the tested concentration. Similar results were obtained on C. parapsilosis biofilms using d-AmB at $75 \mu \mathrm{g} / \mathrm{mL}$ to $250 \mu \mathrm{g} / \mathrm{mL}$. Ko et al. also investigated in vitro the interest of $\mathrm{d}-\mathrm{AmB}$ lock solutions in inhibiting mature (5-day old) biofilms [36]. C. albicans, C. glabrata and C. tropicalis species (one strain of each) were investigated and d-AmB minimal inhibitory concentrations for biofilm cells (CFU method, polyurethane surfaces) were rather low: $16 \mathrm{mg} / \mathrm{mL}, 32 \mathrm{mg} / \mathrm{mL}$ and $4 \mathrm{mg} / \mathrm{mL}$, respectively. However, as previously mentioned, these authors reported rather divergent results, and found that tested azole compounds were generally superior to d-AmB in eradication of Candida biofilms. Finally, Fiori et al. reported on the in vitro anti-biofilm activity of d-AmB lock solutions against C. albicans, C. glabrata, C. tropicalis, C. krusei (20 strains of each) and C. parapsilosis (40 strains) assessing the inhibition of sessile yeast metabolism caused by the drug (XTT method) [37]. They reported that the lowest d-AmB concentrations at which $50 \%$ decrease in biofilm was observed ranged from $0.5 \mu \mathrm{g} / \mathrm{mL}$ to $>32 \mu \mathrm{g} / \mathrm{mL}$ for all tested strains of C. albicans, C. glabrata, C. parapsilosis, and C. tropicalis, and from $1 \mu \mathrm{g} / \mathrm{mL}$ to $>32 \mu \mathrm{g} / \mathrm{mL}$ for those of C. krusei. Actually, the concentration responsible for $50 \%$ biofilm inhibition was $\leq 1 \mu \mathrm{g} / \mathrm{mL}$ for $45 \%$ (C. parapsilosis), $40 \%$ (C. tropicalis), 30\% (C. albicans and C. glabrata) and only $1 \%$ (C. krusei) of the studied strains. Furthermore, the concentrations causing $90 \%$ decrease were $>32 \mu \mathrm{g} / \mathrm{mL}$ for C. albicans, C. parapsilosis and C. krusei strains, whereas they were $32 \mu \mathrm{g} / \mathrm{mL}$ and $16 \mu \mathrm{g} / \mathrm{mL}$ for C. tropicalis and C. glabrata strains. Finally, even if d-AmB lock solutions displayed little activity against sessile Candida yeasts, these results based on the investigation of numerous strains of each studied Candida species clearly demonstrated that this activity was both limited and strain- dependent.

However, some early in vitro experiments demonstrated the anti-biofilm activity of lipid formulations of amphotericin B, such as ABLC, and their significantly higher anti-biofilm activity against $C$. albicans and C. parapsilosis compared to d-AmB [6]. Three studies published between 2012 and 2016 studying different Candida species focused on the efficiency of L-AMB lock solutions in fighting Candida biofilms $[27,39,44]$. Toulet et al. investigated in vitro the activity of L-AmB solutions at $200 \mu \mathrm{g} / \mathrm{mL}$ and $1000 \mu \mathrm{g} / \mathrm{mL}$ against biofilms of C. albicans, C. parapsilosis and C. glabrata on silicone catheters ( 2 strains of each species, XTT method) and aged $12 \mathrm{~h}$ or 5 days. Their efficacy was analysed depending on lock duration $(4 \mathrm{~h}, 12 \mathrm{~h}$ or $24 \mathrm{~h}$ ) and in each case the authors evaluated post-lock remanence [27]. They showed that L-AmB solutions used at $1000 \mu \mathrm{g} / \mathrm{mL}$ reduced $12 \mathrm{~h}$ and 5-day-old Candida spp. biofilms regardless of lock duration (inhibition always $\geq 80 \%$ for C. albicans and C. glabrata and $\geq 62 \%$ for $C$. glabrata), but could never totally eradicate biofilms. Lower activities were obtained using L-AmB at $200 \mathrm{~g} / \mathrm{mL}$, with inhibition percentages for C. albicans, C. glabrata and C. parapsilosis ranging from $73.5 \%$ to $91.5 \%, 77.5 \%$ to $93 \%$ and $41.5 \%$ to $88.5 \%$, respectively. This study showed that L-AmB solutions at $1000 \mu \mathrm{L} / \mathrm{mL}$ used for short lock times $(\leq 4 \mathrm{~h})$ could significantly reduce biofilms of C. albicans and C. glabrata for up to $48 \mathrm{~h}$ (post-lock remanence) but were less efficient against C. parapsilosis biofilms. Basas et al. also evaluated the efficacy of L-AmB in reducing mature biofilms (48 h-old) of C. parapsilosis on silicone surfaces, studying two strains [40]. They reported that the lowest L-AmB concentrations causing a 50\% and a 90\% decrease in C. parapsilosis biofilm were $0.5 \mathrm{or} 1 \mu \mathrm{g} / \mathrm{mL}$ (depending on the strain) and $>1024 \mu \mathrm{g} / \mathrm{mL}$, respectively, confirming how difficult it is to totally eradicate biofilms, even if the drug remains effective. Biofilm reduction was evaluated according to decreases in yeast viability (Live/dead staining) and metabolism (XTT method). Interestingly, these authors compared L-AmB activities depending on the biofilm substrate and showed that $48 \mathrm{~h}$-old 
biofilms formed on polystyrene surfaces were much easier to reduce compared to those prepared on silicone: $50 \%$ biofilm reduction at $0.125 \mu \mathrm{g} / \mathrm{mL}$ or $0.25 \mu \mathrm{g} / \mathrm{mL}$ depending on the strain, and $90 \%$ reduction at $8 \mu \mathrm{g} / \mathrm{mL}$ or $16 \mu \mathrm{g} / \mathrm{mL}$. This finding highlights the influence of substrates and the need to use materials mimicking those used to manufacture medical devices. Finally, Simitsopolous et al. investigated in vitro the interest of $\mathrm{L}-\mathrm{AmB}$ against mature biofilms ( $48 \mathrm{~h}$-old) of C. albicans ( 1 strain), C. lusitaniae (6 strains) and C. guilliermondii (5 strains) using both metabolic (XTT) and viability (CFU counts) approaches, considering locks for $24 \mathrm{~h}$ [39]. In these conditions, the lowest L-AmB concentrations causing $50 \%$ decrease in biofilms were $0.25 \mu \mathrm{g} / \mathrm{mL}, 2 \mu \mathrm{g} / \mathrm{mL}$ and $0.125 \mu \mathrm{g} / \mathrm{mL}$ for C. albicans, C. guilliermondii and C. lusitaniae, respectively, which seems close to the results presented by Fiori et al. [37]. At $256 \mu \mathrm{g} / \mathrm{mL}$ to $2048 \mu \mathrm{g} / \mathrm{mL}, \mathrm{L}-\mathrm{AmB}$ induced strong biofilm damage against C. albicans (about $80 \%$ to $90 \%$ decrease), which is consistent with the results of Toulet et al. [27].

Few patients have been treated with d-AmB antifungal lock [25,45-50] (Table 2). d-AmB antifungal lock has been shown to be effective in 6/10 patients. However, failures of therapy are often unpublished. In addition, the patients received different systemic antifungal therapies that were likely to bias analysis of these data [25]. Nevertheless, $\mathrm{d}-\mathrm{AmB}$ as an antifungal lock failed to find a place in a clinical setting, and was not reinforced by animal models. Indeed, the only experimental in vivo model comparing $\mathrm{d}-\mathrm{AmB}$ and caspofungin was favoured of caspofungin [51]. Shuford et al. used a rabbit model of C. albicans catheter-related bloodstream infection (CRBSI). A silicone catheter was inserted into the external jugular vein of the rabbit. The infected catheter was used daily to administered an antifungal drug and was locked after injection with a solution containing heparin and the antifungal drug. Using d-AmB, 13/16 catheters were sterile at day 7 compared to all catheters locked with caspofungin [51].

The other in vivo models focused on lipid forms of Amphotericin B. Mukherjee et al. used a rabbit model of C. albicans CRBSI to test antifungal lock with ABLC [52]. A silicone catheter was locked for 4 or $8 \mathrm{~h}$ per day with a solution containing ABLC and heparinized saline. At day 11 of antifungal lock, ABLC-locked catheters were all sterilized compared to control, whatever the duration of lock therapy. In another model, L-AmB was superior to fluconazole in eradicating C. albicans biofilm [44]. All these animal studies used C. albicans and silicone catheters.

L-AmB has been used as lock therapy for few patients [53-55] (Table 2). L-AmB lock was used in a patient on hemodialysis with persistent CRBSI due to $C$. albicans on a polyurethane catheter [53]. The catheter could not be removed due to lack of other available sites for vascular access. It was exchanged over a wire. A lock solution containing $2.67 \mathrm{mg} / \mathrm{mL}$ of L-AmB in $5 \%$ dextrose plus $200 \mathrm{UI}$ $(66 \mathrm{UI} / \mathrm{mL})$ of heparin was prepared and dwelled for $12 \mathrm{~h}$ in the lumen of the new catheter. Antifungal lock with L-AmB was continued for 6 days concomitantly with systemic micafungin. Systemic antifungal treatment was prolonged 6 months without any relapse of fungal infection. The same protocol of L-AmB lock was used for the other cases, leading to success in $7 / 8$ episodes [54,55].

The only clinical prospective study of antifungal lock came from a pediatric context [56]. This study involved L-AmB and various polyurethane and silicone central venous catheters (CVC) from different manufacturers. L-AmB solution at $2 \mathrm{mg} / \mathrm{mL}$ was instilled daily into the catheter in 12 children having 13 episodes of Candida CRBSI [56]. The antifungal solution dwelled for $8-12 \mathrm{~h}$ in the catheter lumen. All children received an additional systemic antifungal drug, either caspofungin or L-AmB. Blood cultures from each line of the CVC were collected every day. The species involved were C. albicans, C. glabrata, C. lusitaniae, C. parapsilosis, and Rhodotorula rubra. The primary endpoint was two consecutive negative CVC-bloodcultures within 5 days of initiating antifungal lock. A total of 10 infections in 10 patients $(77 \%)$ met the primary endpoint, and cure without relapse was obtained in 5 of 13 (38\%) infections. Culture became negative within 2.4 days (range 1-5 days). Although the number of patients of this pilot study was insufficient to conclude that L-AmB antifungal lock was fully effective, it provided encouraging results. 
Table 2. Antifungal lock in clinical setting. Only cases with sufficient data were included in the table. For all cases, see ref [25]. There is no data for azole antifungal lock or other type of echinocandins. $\mathrm{d}-\mathrm{AmB}=$ Amphotericin B deoxycholate; L-AmB = liposomal Amphotericin B; ALT: antifungal lock treatment; BC: blood culture.

\begin{tabular}{|c|c|c|c|c|c|c|c|}
\hline Pient Age & $\begin{array}{l}\text { Episode } \\
\text { Number }\end{array}$ & $\begin{array}{l}\text { Systemic Antifungal } \\
\text { Treatment }\end{array}$ & ALT Duration & Antifungal Lock Solution & Fungus & Major Conclusion & Reference \\
\hline \multicolumn{8}{|c|}{ deoxycholate AmB } \\
\hline 35 у.о. & 1 & No systemic therapy & $12 \mathrm{~h} /$ day for 21 days & $\mathrm{d}-\mathrm{AmB} 2.5 \mathrm{mg} / \mathrm{mL}$ & Malassezia furfur & $\begin{array}{l}\text { Success; BC negative after } 7 \text { days of ALT; } \\
\text { fever resolution after } 2 \text { days of ALT }\end{array}$ & Arnow et al. [46] \\
\hline 30 у.о. & 1 & $\begin{array}{l}\mathrm{d} \text {-AmB for } 3 \text { days then } \\
\text { fluconazole for } 4 \text { days }\end{array}$ & $8-12 \mathrm{~h} /$ day for 15 days & $\mathrm{d}-\mathrm{AmB} 2.5 \mathrm{mg} / \mathrm{mL}$ & C. glabrata & Initial success but relapse 6 weeks later; no details on $B C$ & \multirow{3}{*}{ Benoit et al. [47] } \\
\hline \multirow[t]{2}{*}{40 у.о. } & 1 & d-Amb for 1 day & $6 \mathrm{~h} /$ day for 7 months & $\mathrm{d}-\mathrm{AmB} 2.5 \mathrm{mg} / \mathrm{mL}$ & C. albicans + C. glabrata & $\begin{array}{l}\text { Eradiaction of C. albicans but failure for C. glabrata that } \\
\text { recurred } 5 \text { days after ALT discontinuation }\end{array}$ & \\
\hline & 2 & Fluconazole for 3 days & $6 \mathrm{~h} /$ day for 8 months & $\mathrm{d}-\mathrm{AmB} 2.5 \mathrm{mg} / \mathrm{mL}$ & C. glabrata & $\begin{array}{l}\text { Successafter } 8 \text { months of ATL; BC negative for } 8 \text { months; } \\
\text { no data after ALT withdrawal }\end{array}$ & \\
\hline 13 y.o. & 1 & $\begin{array}{l}\mathrm{d}-\mathrm{AmB} \text { for } 6 \text { days then } \\
\text { fluconazole (no duration) }\end{array}$ & $24 \mathrm{~h} /$ day for 20 days & $\mathrm{d}-\mathrm{AmB} 2.5 \mathrm{mg} / \mathrm{mL}$ & C. parapsilosis & $\begin{array}{l}\text { Success; ALT started after } 6 \text { days of systemic } \\
\text { antifungal therapy; }\end{array}$ & Wu et al. [48] \\
\hline 2 у.о. & 1 & d-AmB for 7 days & $12 \mathrm{~h} /$ day for 14 days & $\mathrm{d}-\mathrm{AmB} 2.5 \mathrm{mg} / \mathrm{mL}$ & C. albicans & $\begin{array}{l}\text { Success; fever resolution after } 3 \text { days of ALT; BC } \\
\text { negative at the end of ALT }\end{array}$ & \multirow[t]{2}{*}{ Viale et al. [49] } \\
\hline 65 у.о. & 1 & Fluconazole for 7 days & $12 \mathrm{~h} /$ day for 14 days & $\mathrm{d}-\mathrm{AmB} 2.5 \mathrm{mg} / \mathrm{mL}$ & C. albicans & $\begin{array}{c}\text { Success; fever resolution after } 4 \text { days of ALT; BC } \\
\text { negative at the end of ALT }\end{array}$ & \\
\hline 40 у.о. & 1 & Fluconazole (no duration) & $6 \mathrm{~h} /$ day for 14 days & $\mathrm{d}-\mathrm{AmB} 5 \mathrm{mg} / \mathrm{mL}$ & C. glabrata & $\begin{array}{l}\text { Success; ALT started } 2 \text { days after antifungal systemic; } \\
\text { surveillance BC negative; no further details }\end{array}$ & $\begin{array}{l}\text { Angel-Moreno et al. } \\
\text { [50] }\end{array}$ \\
\hline \multicolumn{8}{|c|}{ liposomal AmB } \\
\hline infant & 1 & L-AmB for 14 days & $8 \mathrm{~h} /$ day for 14 days & $2.67 \mathrm{mg} / \mathrm{mL}+$ heparin $100 \mathrm{UI}$ & C. parapsilosis & Success; BC negative after 2 days of ALT & $\begin{array}{l}\text { Castagnola et al. } \\
\text { [53] }\end{array}$ \\
\hline \multirow{3}{*}{$\begin{array}{c}17 \\
\text { month-old }\end{array}$} & 1 & L-AmB for 8 days & $8 \mathrm{~h} /$ day for 7 days & $2.67 \mathrm{mg} / \mathrm{mL}+$ heparin $200 \mathrm{UI}$ & C. glabrata + C. albicans & Success; ALT started at $24 \mathrm{~h}$ of systemic treatment & \multirow{6}{*}{ Buckler et al. [54] } \\
\hline & 2 & L-AmB for 10 days & $8 \mathrm{~h} /$ day for 10 days & $2.67 \mathrm{mg} / \mathrm{mL}+$ heparin $200 \mathrm{UI}$ & C. albicans + C. glabrata & $\begin{array}{l}\text { Failure; no details } \\
\end{array}$ & \\
\hline & 3 & L-AmB for 16 days & $8 \mathrm{~h} /$ day for 16 days & $2.67 \mathrm{mg} / \mathrm{mL}+$ heparin $200 \mathrm{UI}$ & C. glabrata & Success; BC negative after 6 days of ALT & \\
\hline 7 y.o. & 1 & L-AmB for 21 days & $8 \mathrm{~h} /$ day for 17 days & $2.67 \mathrm{mg} / \mathrm{mL}+$ heparin $200 \mathrm{UI}$ & C. albicans & $\begin{array}{l}\text { Success; ALT started at } 24 \mathrm{~h} \text {; BC negative after } \\
24 \mathrm{~h} \text { of ALT }\end{array}$ & \\
\hline $\begin{array}{c}6 \\
\text { month-old }\end{array}$ & 1 & L-AmB for 15 days & $8 \mathrm{~h} /$ day for 15 days & $2.67 \mathrm{mg} / \mathrm{mL}+$ heparin $200 \mathrm{UI}$ & C. parapsilosis & Success; BC negative after 8 days of ALT & \\
\hline 1 y.o. & 1 & L-AmB for 14 days & $8 \mathrm{~h} /$ day for 14 days & $2.67 \mathrm{mg} / \mathrm{mL}+$ heparin $200 \mathrm{UI}$ & C. guillermondii & Success; BC negative after 3 days of ALT & \\
\hline 64 y.o. & 1 & Micafungin for 14 days & $\begin{array}{l}24 \mathrm{~h} / \text { day, change every } \\
12 \mathrm{~h} \text {, for } 6 \text { days }\end{array}$ & $2.67 \mathrm{mg} / \mathrm{mL}+$ heparin $200 \mathrm{UI}$ & C. albicans & $\begin{array}{l}\text { Success; BC negative before initiation of ALT; ALT } \\
\text { started after catheter exchange over a wire and after } \\
9 \text { days of systemic antifungal }\end{array}$ & $\begin{array}{l}\text { Paul Dimondi et al. } \\
\text { [55] }\end{array}$ \\
\hline \multicolumn{8}{|c|}{ Caspofungin } \\
\hline 9 y.o. & 1 & caspofungin & $12 \mathrm{~h} /$ day for 14 days & $3.33 \mathrm{mg} / \mathrm{mL}+$ heparin $200 \mathrm{UI}$ & C. lipolytica & Success; BC negative after 4 days of ALT & Özdemir et al. [52] \\
\hline 1.5 y.o. & 1 & caspofungin & $12 \mathrm{~h} /$ day for 14 days & $3.33 \mathrm{mg} / \mathrm{mL}+$ heparin $200 \mathrm{UI}$ & C. parapsilosis & $\begin{array}{l}\text { Failure; ALT started } 7 \text { days after systemic caspofungin: } \\
\text { BC still positive at } 14 \text { days }\end{array}$ & Isgüder et al. [51] \\
\hline
\end{tabular}


Finally, available data obtained with in vitro models generally suggest better activity of L-AmB lock solutions compared to d-AmB lock-solutions; they suggest that L-AmB lock solutions could help to significantly reduce Candida spp. mature biofilms without being able to totally eradicate sessile yeasts. They highlight the influence of both the nature of the substrate (polystyrene, silicone, polyurethane, and so on), lock duration, and age of the treated biofilm.

\section{Echinocandin Lock Solutions}

Echinocandins act by inhibiting the biosynthesis of 1.3-beta-glucans, which are key constituents of the fungal cell wall, and this mode of action has encouraged researchers to investigate their anti-biofilm activity. The anti-adherent and anti-biofilm interest of echinocandins was rapidly shown, even using low concentrations, close to MIC [6,9]. More recently, a study done on more than 200 Candida isolates helped to show that whereas fluconazole belonged to non-active anti-biofilm agents, caspofungin belonged to highly active anti-biofilm agents [24]. Anidulafungin, caspofungin and micafungin all belong to echinocandins, and yet most studies investigating the echinocandin possibly used in lock therapy focus on caspofungin, and to a lesser extent on micafungin and anidulafungin.

Cateau et al. have developed an in vitro model to evaluate the effect of a $12 \mathrm{~h}$ lock with caspofungin $(2 \mu \mathrm{g} / \mathrm{mL})$ or micafungin $(5 \mu \mathrm{g} / \mathrm{mL})$ solutions against young ( $12 \mathrm{~h}$ old) or mature (5 days old) C. albicans on silicone surfaces; tested concentrations corresponded to about 100 times MIC and anti-biofilm activity was evaluated based on reduction in the metabolic activity of sessile yeasts (XTT method) [35]. Their results showed that even $48 \mathrm{~h}$ after the end of the lock, $12 \mathrm{~h}$ and 5-day-old biofilms treated by caspofungin and micafungin were still inhibitedby at least $55 \%$ (caspofungin: $\approx 60 \%$ to $\approx 90 \%$ ) (micafungin: $\approx 55 \%$ to $\approx 92 \%$ ) and $47 \%$ (caspofungin: $\approx 47 \%$ to $\approx 88 \%$ ) (micafungin: $\approx 54 \%$ to $\approx 91 \%$ ), respectively. The weakness of this study is that only two C. albicans strains were studied and that they were collection instead of clinical strains. However, the same lock-model was then applied to biofilms prepared in the same manner, with all 8 C. albicans and 6 C. glabrata clinical strains isolated from infected catheters, and this confirmed the interest of echinocandin lock-solutions [26]. C. glabrata clinical strains were all isolated from infected catheters, and thereby confirmed the interest of echinocandin lock-solutions. Irrespective of antifungal concentration and biofilm age $(12 \mathrm{~h}$ or 5 days old), echinocandins still inhibited C. albicans biofilms by at least $65 \%$ (caspofungin: inhibition $\geq \approx 77 \%$, micafungin: $\geq \approx 65 \%$ ) $48 \mathrm{~h}$ after the end of the lock. The strain dependence of results was mentioned in the case of mature 5-day-old biofilm but not for $12 \mathrm{~h}$ ones. Regarding C. glabrata biofilms, inhibitory percentages caused by caspofungin at $5 \mathrm{~g} / \mathrm{mL}$ were still at least $55.8 \%$ ( $12 \mathrm{~h}$ biofilms) or $44.4 \%$ ( 5 days old) $48 \mathrm{~h}$ after the end of the lock compared to those of micafungin at $5 \mathrm{~g} / \mathrm{mL}$ which were still at least $92.4 \%$ ( $12 \mathrm{~h}$ old biofilms) or $90.3 \%$ ( 5 days old). So, micafungin showed greater sustained efficacy than caspofungin against both $12 \mathrm{~h}$ and 5-day-old biofilms of C. glabrata, whereas there was no obvious difference in the case of $C$. albicans biofilms. In any event, none of the tested conditions totally eradicated biofilms, as was reported by the same team regarding L-AmB [27]. Öncü studied the killing activity (CFU counts) of caspofungin solutions (300 to 1000 times MIC) against 5-day-old biofilms on silicone catheters; the lock periods were 1,3,5 and 7 days, caspofungin solutions being replaced every 2 days) [38]. The weakness of this study is that only two strains were studied, one from each species. The results showed that, for both C. albicans and C. parapsilosis biofilms, caspofungin lock solutions significantly decreased the number of yeasts inside catheters, starting on the first day of the treatment, and the catheters were completely sterile at the fifth day, which corresponds to efficacy comparable to that reported by this author using amphotericin B, as mentioned in the previous part.

Unlike others, Ko et al. reported quite low activity (CFU method) of caspofungin lock solutions against 5-day-old biofilms of C. albicans and C. glabrata on polyurethane surfaces, the lowest caspofungin concentrations at which a $50 \%$ decrease in biofilm was observed remaining $>256 \mu \mathrm{g} / \mathrm{mL}$ [36].

Only the study of Simitsopoulou et al. compared the activity on anidulafungin, caspofungin and micafungin lock solutions for $24 \mathrm{~h}$ against metabolism and cultivability of sessile yeasts from mature (48 h old) biofilms of C. albicans; however, they considered only one collection strain [39]. 
The lowest average concentrations at which a 50\% decrease in C. albicans biofilm was observed were very close to each other, whatever the tested drug: $0.25 \mu \mathrm{g} / \mathrm{mL}$ for both micafungin and anidulafungin and $0.5 \mu \mathrm{g} / \mathrm{mL}$ for caspofungin. However, the highest inhibition of sessile yeast metabolism reached $100 \%$ and was only obtained by caspofungin, the other echinocandins being less active. This was similar to results reported by the team using L-AmB, as mentioned in the previous part; taken as a whole these results suggested the high and comparable in vitro efficacy of L-AmB and caspofungin against mature biofilms of C. albicans. Simitsopoulou et al. extended the study to 6 and 5 clinical strains of $C$. lusitaniae and C. guilliermondii, respectively and showed that anidulafungin and micafungin had reduced activity against $C$. lusitaniae and C. guilliermondii biofilms compared with caspofungin: the lowest concentration of anidulafungin and micafungin at which a $50 \%$ decrease in biofilm was observed ranged from $32 \mu \mathrm{g} / \mathrm{mL}$ to $>2,048 \mu \mathrm{g} / \mathrm{mL}$, biofilms of C. lusitaniae being the most resistant [39]. Interestingly, caspofungin was the most active agent against C. lusitaniae and C. guilliermondii biofilms, achieving complete and persistent (up to $72 \mathrm{~h}$ post-lock) biofilm eradication at lock concentrations ranging from between $512 \mu \mathrm{g} / \mathrm{mL}$ to $2048 \mu \mathrm{g} / \mathrm{mL}$ depending on the tested strains. Fiori et al. compared the anti-biofilm activity of anidulafungin and caspofungin lock solutions in the presence or absence of 50\% serum, studying numerous clinical strains of 5 Candida species [37]. Overall, the presence of serum increased concentrations at which a 50\% decrease in biofilm was observed, whatever the tested echinocandin, and these concentrations were generally lower for anidulafungin compared to caspofungin, suggesting the superiority of anidulafungin against sessile yeasts. More precisely, in presence of serum, concentrations were relatively close for C. albicans and C. tropicalis biofilms, ranging from $0.5 \mu \mathrm{g} / \mathrm{mL}$ to $2 \mu \mathrm{g} / \mathrm{mL}$ (anidulafungin) or $2 \mu \mathrm{g} / \mathrm{mL}$ to $8 \mu \mathrm{g} / \mathrm{mL}$ (caspofungin) and $1 \mu \mathrm{g} / \mathrm{mL}$ to $4 \mu \mathrm{g} / \mathrm{mL}$ (anidulafungin) or $2 \mu \mathrm{g} / \mathrm{mL}$ to $8 \mu \mathrm{g} / \mathrm{mL}$ (caspofungin), respectively. Anidulafungin was clearly more active against $C$. glabrata (between $1 \mu \mathrm{g} / \mathrm{mL}$ and $2 \mu \mathrm{g} / \mathrm{mL}$ (anidulafungin) or between $2 \mu \mathrm{g} / \mathrm{mL}$ and $16 \mu \mathrm{g} / \mathrm{mL}$ (caspofungin)) and C. krusei (between $4 \mu \mathrm{g} / \mathrm{mL}$ and $16 \mu \mathrm{g} / \mathrm{mL}$ (anidulafungin) or $\geq 8 \mu \mathrm{g} / \mathrm{mL}$ (caspofungin)). However, both were only weakly active against $C$. parapsilosis $(\geq 4 \mu \mathrm{g} / \mathrm{mL})$. Finally, the results of Basas et al. were based on metabolic (XTT method) and viability tests (staining) and underscored the high efficacy of anidulafungin against C. parapsilosis mature biofilms ( $48 \mathrm{~h}$-old) on silicone surfaces: they reported a concentration at which a $50 \%$ or $90 \%$ decrease in biofilm was observed $\leq 0.25 \mu \mathrm{g} / \mathrm{mL}$ or equal to $1 \mu \mathrm{g} / \mathrm{mL}$. Under the test conditions, anidulafungin thus appeared much more effective than L-AmB [40]. Lown et al. recently studied the efficacy of a $24 \mathrm{~h}$ lock treatment based on micafungin used alone or combined with ethanol and/or doxycycline in eradicating a $24 \mathrm{~h}$-old biofilm developed in polystyrene microplate wells under static conditions [41]. Five C. albicans strains were studied, two clinical ones, derived echinocandin-resistant isolates and three collection ones, and anti-biofilm activity was evaluated with metabolic (XTT) and cultivability (CFU counts) assays. The results demonstrated that the combination comprising $20 \%$ ethanol, $0.01565 \mu \mathrm{g} / \mathrm{mL}$ micafungin and $800 \mathrm{~g} / \mathrm{mL}$ doxycycline was highly effective against both forming and mature C. albicans. This combined lock-solution reduced the metabolic activity of treated biofilms to $\leq 2 \%$, and prevented the regrowth from both forming and mature biofilms; however, this solution was not more active than $20 \%$ ethanol used alone. By using a three-drug lock therapy approach, authors wished to maximize the broad-spectrum activity of the solution to include both yeasts and bacteria, which would also probably reduce the risk for resistance development.

Lown et al. have mentioned that only limited investigations have been performed on the effect of high concentrations of ethanol on catheter integrity, depending on the material. Use of such a complex three-drug lock solution may consequently help to minimize the ethanol concentration used. An approach combining a 1:1 mixture of 70\% ethanol and micafungin $5 \mathrm{mg} / \mathrm{L}$ was applied as antifungal lock therapy to treat a preterm infant for $C$. albicans CRBSI [57]. The patient also received systemic L-AmB at $5 \mathrm{mg} / \mathrm{kg} /$ day. The lock solution dwelled for $12 \mathrm{~h}$. After $48 \mathrm{~h}$ a combination therapy of L-AmB and micafungin for persistent positive blood cultures was administered, and the catheter was locked again for another $12 \mathrm{~h}$ with success. Systemic antifungal therapy was discontinued after 
21 days. The stability of the lock mixture was tested using high-performance liquid chromatography dosages. The solution of micafungin plus ethanol was stable for at least $24 \mathrm{~h}$.

Caspofungin lock was likewise effective against $C$. albicans CRBSI after $24 \mathrm{~h}$ in a mouse model of catheter infection [58]. Catheters recovered from caspofungin pre-treated animals had significantly less biofilm formation compared with untreated controls. There was also a significant decrease in dissemination to kidneys with caspofungin. In the clinical setting, Isguder et al. reported a case of $C$. parapsilosis antifungal lock failure with caspofungin [59] (Table 2). The antifungal lock was started 7 days after the systemic caspofungin and failed to sterilize the CVC. The solution was at a concentration of $3.3 \mathrm{mg} / \mathrm{mL}$ with 200 UI of heparin. The authors underlined that optimal concentration of caspofungin lock has not yet been determined. However, another team reported the success of caspofungin lock with the same antifungal lock protocol in a 9-year-old child for C. lipolytica CRBSI [60]. The antifungal lock was instilled on the same day as systemic antifungal drug administration. Since the formation of Candida biofilm on catheter is known to occur within $24 \mathrm{~h}$, the timing of antifungal lock instillation in the catheter may be crucial to success [61].

Antifungal lock with echinocandins seems to be more effective than that with L-AmB, at least in animal models, as no comparative clinical data are available [40]. A silicone CVC was inserted into New Zealand white male rabbits' jugular vein, and then filled with C. parapsilosis. A lock containing anidulafungin at $3.3 \mathrm{mg} / \mathrm{mL}$ or L-AmB at $5.5 \mathrm{mg} / \mathrm{mL}$ supplemented with 100 UI of sodium heparin $/ \mathrm{mL}$ was carried out. After $48 \mathrm{~h}$ of antifungal lock, anidulafungin achieved a significant reduction of fungal load and a significant percentage of negative catheter cultures compared to L-AmB. No data were provided concerning the stability of antifungal solution that dwelled for $48 \mathrm{~h}$. Stability and compatibility of antifungal drugs with other solutions has yet to be extensively studied [62]. It has been reported that caspofungin acetate may be precipitated in a solution with heparin. This phenomenon was concentration-dependent with EDTA [62]. Micafungin seemed physically stable for $24 \mathrm{~h}$ in combination with heparin sodium at ambient room temperature, as did ABLC with EDTA for at least $8 \mathrm{~h}[62,63]$.

\section{Conclusions}

The best antifungal lock solution has to be active, whatever be the catheter material. It has to eradicate biofilm in a timely manner, dwelling less than $12 \mathrm{~h}$ in order to allow the patient to continue another systemic treatment or parenteral nutrition. It has to remain stable with anticoagulant agents being used to avoid catheter thrombosis. The anti-biofilm activity of lock solutions based on echinocandins and lipid formulations of amphotericin $B$ has been widely investigated in vitro and their efficacy has been convincingly demonstrated. However, the experimental conditions used by authors are too variable to draw any conclusion as to which of the solutions are the most active. However, the presently available in vitro results suggest the promise of lipid formulations of amphotericin $\mathrm{B}$ and echinocandins used as lock solutions to maintain catheters in patients when their removal is not possible. Importantly, according to the reported studies total eradication of sessile yeasts is rarely achieved, and when it is, obtained, usually the described conditions do not seem compatible with a lock therapy, especially on account of long lock duration (often at least $24 \mathrm{~h}$ ). To conclude, caspofungin, micafungin, anidulafungin and L-AmB are good candidates for lock therapy in further clinical studies, but have imperatively to be combined with systemic therapy. On this subject, the interest of combining a lipid amphotericin B formulation and an echinocandin, one for lock-treatment and the other for systemic treatment, needs to be further investigated and evaluated, while bearing in mind that approach could effectively combat Candida spp. biofilms. In addition, further in vivo studies should be focused on the different materials used in the daily clinical practice (polyurethane, silicone).

Acknowledgments: Jeffrey Arsham for editing our original English language manuscript.

Author Contributions: All authors contributed equally to the work. 
Conflicts of Interest: B.R. received speaker fees from Gilead, Basilea, Merck, Astellas, and travel grant for conferences from Pfizer. C.H. received speaker fees from Gilead and travel grants for conferences from Astellas, Pfizer and Gilead.

\section{References}

1. Mayer, F.L.; Wilson, D.; Hube, B. Candida albicans pathogenicity mechanisms. Virulence 2013, 4, 119-128. [CrossRef] [PubMed]

2. Nikawa, H.; Nishimura, H.; Hamada, T.; Makihira, S.; Samaranayake, L.P. Relationship between thigmotropism and Candida biofilm formation in vitro. Mycopathologia 1998, 144, 125-129. [CrossRef] [PubMed]

3. Hirota, K.; Yumoto, H.; Sapaar, B.; Matsuo, T.; Ichikawa, T.; Miyake, Y. Pathogenic factors in Candida biofilm-related infectious diseases. J. Appl. Microbiol. 2017, 122, 321-330. [CrossRef] [PubMed]

4. Costerton, J.W.; Stewart, P.S.; Greenberg, E.P. Bacterial biofilms: A common cause of persistent infections. Science 1999, 284, 1318-1322. [CrossRef] [PubMed]

5. Mukherjee, P.K.; Chandra, J. Candida biofilm resistance. Drug Resist. Updat. 2004, 7, 301-309. [CrossRef] [PubMed]

6. Kuhn, D.M.; George, T.; Chandra, J.; Mukherjee, P.K.; Ghannoum, M.A. Antifungal susceptibility of Candida biofilms: Unique efficacy of amphotericin B lipid formulations and echinocandins. Antimicrob. Agents Chemother. 2002, 46, 1773-1780. [CrossRef] [PubMed]

7. Uppuluri, P.; Pierce, C.G.; López-Ribot, J.L. Candida albicans biofilm formation and its clinical consequences. Future Microbiol. 2009, 4, 1235-1237. [CrossRef] [PubMed]

8. Uppuluri, P.; Chaturvedi, A.K.; Srinivasan, A.; Banerjee, M.; Ramasubramaniam, A.K.; Köhler, J.R.; Kadosh, D.; Lopez-Ribot, J.L. Dispersion as an important step in the Candida albicans biofilm developmental cycle. PLoS Pathog. 2010, 6, e1000828. [CrossRef] [PubMed]

9. Cocuaud, C.; Rodier, M.-H.; Daniault, G.; Imbert, C. Anti-metabolic activity of caspofungin against Candida albicans and Candida parapsilosis biofilms. J. Antimicrob. Chemother. 2005, 56, 507-512. [CrossRef] [PubMed]

10. Moran, C.; Grussemeyer, C.A.; Spalding, J.R.; Benjamin, D.K.; Reed, S.D. Candida albicans and non-albicans bloodstream infections in adult and pediatric patients: Comparison of mortality and costs. Pediatr. Infect. Dis. J. 2009, 28, 433-435. [CrossRef] [PubMed]

11. Baldesi, O.; Bailly, S.; Ruckly, S.; Lepape, A.; L'Heriteau, F.; Aupee, M.; Boussat, S.; Bervas, C.; Machut, A.; Berger-Carbonne, A.; et al. REA-RAISIN network ICU-acquired candidemia in France: Epidemiology and temporal trends, 2004-2013-A study from the REA-RAISIN network. J. Infect. 2017, 75, 59-67. [CrossRef] [PubMed]

12. Blot, S.I.; Vandewoude, K.H.; Hoste, E.A.; Colardyn, F.A. Effects of nosocomial candidemia on outcomes of critically ill patients. Am. J. Med. 2002, 113, 480-485. [CrossRef]

13. Arendrup, M.C.; Bruun, B.; Christensen, J.J.; Fuursted, K.; Johansen, H.K.; Kjaeldgaard, P.; Knudsen, J.D.; Kristensen, L.; Møller, J.; Nielsen, L.; et al. National surveillance of fungemia in Denmark (2004 to 2009). J. Clin. Microbiol. 2011, 49, 325-334. [CrossRef] [PubMed]

14. Marcos-Zambrano, L.J.; Escribano, P.; González del Vecchio, M.; Bouza, E.; Guinea, J. Micafungin is more active against Candida albicans biofilms with high metabolic activity. J. Antimicrob. Chemother. 2014, 69, 2984-2987. [CrossRef] [PubMed]

15. Høiby, N.; Bjarnsholt, T.; Moser, C.; Bassi, G.L.; Coenye, T.; Donelli, G.; Hall-Stoodley, L.; Holá, V.; Imbert, C.; Kirketerp-Møller, K.; et al. ESCMID Study Group for Biofilms and Consulting External Expert Werner Zimmerli ESCMID guideline for the diagnosis and treatment of biofilm infections 2014. Clin. Microbiol. Infect. 2015, 21 (Suppl. 1), S1-S25. [CrossRef] [PubMed]

16. Mermel, L.A.; Allon, M.; Bouza, E.; Craven, D.E.; Flynn, P.; O'Grady, N.P.; Raad, I.I.; Rijnders, B.J.A.; Sherertz, R.J.; Warren, D.K. Clinical practice guidelines for the diagnosis and management of intravascular catheter-related infection: 2009 Update by the Infectious Diseases Society of America. Clin. Infect. Dis. 2009, 49, 1-45. [CrossRef] [PubMed] 
17. Ullmann, A.J.; Akova, M.; Herbrecht, R.; Viscoli, C.; Arendrup, M.C.; Arikan-Akdagli, S.; Bassetti, M.; Bille, J.; Calandra, T.; Castagnola, E.; et al. ESCMID* guideline for the diagnosis and management of Candida diseases 2012: Adults with haematological malignancies and after haematopoietic stem cell transplantation (HCT). Clin. Microbiol. Infect. 2012, 18 (Suppl. 7), 53-67. [CrossRef] [PubMed]

18. Andes, D.R.; Safdar, N.; Baddley, J.W.; Playford, G.; Reboli, A.C.; Rex, J.H.; Sobel, J.D.; Pappas, P.G.; Kullberg, B.J. Mycoses Study Group Impact of treatment strategy on outcomes in patients with candidemia and other forms of invasive candidiasis: A patient-level quantitative review of randomized trials. Clin. Infect. Dis. 2012, 54, 1110-1122. [CrossRef] [PubMed]

19. Nucci, M.; Colombo, A.L.; Silveira, F.; Richtmann, R.; Salomão, R.; Branchini, M.L.; Spector, N. Risk factors for death in patients with candidemia. Infect. Control Hosp. Epidemiol. 1998, 19, 846-850. [CrossRef] [PubMed]

20. Rex, J.H.; Bennett, J.E.; Sugar, A.M.; Pappas, P.G.; Serody, J.; Edwards, J.E.; Washburn, R.G. Intravascular catheter exchange and duration of candidemia. NIAID Mycoses Study Group and the Candidemia Study Group. Clin. Infect. Dis. 1995, 21, 994-996. [CrossRef] [PubMed]

21. Pappas, P.G.; Kauffman, C.A.; Andes, D.R.; Clancy, C.J.; Marr, K.A.; Ostrosky-Zeichner, L.; Reboli, A.C.; Schuster, M.G.; Vazquez, J.A.; Walsh, T.J.; et al. Clinical Practice Guideline for the Management of Candidiasis: 2016 Update by the Infectious Diseases Society of America. Clin. Infect. Dis. 2016, 62, e1-e50. [CrossRef] [PubMed]

22. Nucci, M.; Anaissie, E.; Betts, R.F.; Dupont, B.F.; Wu, C.; Buell, D.N.; Kovanda, L.; Lortholary, O. Early removal of central venous catheter in patients with candidemia does not improve outcome: Analysis of 842 patients from 2 randomized clinical trials. Clin. Infect. Dis. 2010, 51, 295-303. [CrossRef] [PubMed]

23. Cornely, O.A.; Bassetti, M.; Calandra, T.; Garbino, J.; Kullberg, B.J.; Lortholary, O.; Meersseman, W.; Akova, M.; Arendrup, M.C.; Arikan-Akdagli, S.; et al. ESCMID Fungal Infection Study Group ESCMID* guideline for the diagnosis and management of Candida diseases 2012: Non-neutropenic adult patients. Clin. Microbiol. Infect. 2012, 18 (Suppl. 7), 19-37. [CrossRef] [PubMed]

24. Tumbarello, M.; Fiori, B.; Trecarichi, E.M.; Posteraro, P.; Losito, A.R.; De Luca, A.; Sanguinetti, M.; Fadda, G.; Cauda, R.; Posteraro, B. Risk factors and outcomes of candidemia caused by biofilm-forming isolates in a tertiary care hospital. PLoS ONE 2012, 7, e33705. [CrossRef] [PubMed]

25. Walraven, C.J.; Lee, S.A. Antifungal lock therapy. Antimicrob. Agents Chemother. 2013, 57, 1-8. [CrossRef] [PubMed]

26. Cateau, E.; Berjeaud, J.-M.; Imbert, C. Possible role of azole and echinocandin lock solutions in the control of Candida biofilms associated with silicone. Int. J. Antimicrob. Agents 2011, 37, 380-384. [CrossRef] [PubMed]

27. Toulet, D.; Debarre, C.; Imbert, C. Could liposomal amphotericin B (L-AMB) lock solutions be useful to inhibit Candida spp. biofilms on silicone biomaterials? J. Antimicrob. Chemother. 2012, 67, 430-432. [CrossRef] [PubMed]

28. Uppuluri, P.; Srinivasan, A.; Ramasubramanian, A.; Lopez-Ribot, J.L. Effects of fluconazole, amphotericin B, and caspofungin on Candida albicans biofilms under conditions of flow and on biofilm dispersion. Antimicrob. Agents Chemother. 2011, 55, 3591-3593. [CrossRef] [PubMed]

29. Shuford, J.A.; Piper, K.E.; Steckelberg, J.M.; Patel, R. In vitro biofilm characterization and activity of antifungal agents alone and in combination against sessile and planktonic clinical Candida albicans isolates. Diagn. Microbiol. Infect. Dis. 2007, 57, 277-281. [CrossRef] [PubMed]

30. Dioni, E.; Franceschini, R.; Marzollo, R.; Oprandi, D.; Chirico, G. Central vascular catheters and infections. Early Hum. Dev. 2014, 90 (Suppl. 1), S51-S53. [CrossRef]

31. Cantey, J.B.; Milstone, A.M. Bloodstream infections: Epidemiology and resistance. Clin. Perinatol. 2015, 42, 1-16. [CrossRef] [PubMed]

32. Milstone, A.M.; Reich, N.G.; Advani, S.; Yuan, G.; Bryant, K.; Coffin, S.E.; Huskins, W.C.; Livingston, R.; Saiman, L.; Smith, P.B.; et al. Catheter dwell time and CLABSIs in neonates with PICCs: A multicenter cohort study. Pediatrics 2013, 132, e1609-e1615. [CrossRef] [PubMed]

33. Segarra-Newnham, M.; Martin-Cooper, E.M. Antibiotic lock technique: A review of the literature. Ann. Pharmacother. 2005, 39, 311-318. [CrossRef] [PubMed]

34. Khan, M.S.A.; Ahmad, I.; Sajid, M.; Cameotra, S.S. Current and Emergent Control Strategies for Medical Biofilms. In Antibiofilm Agents; Springer Series on Biofilms; Springer: Berlin/Heidelberg, Germany, 2014; pp. 117-159. ISBN 978-3-642-53832-2. 
35. Cateau, E.; Rodier, M.-H.; Imbert, C. In vitro efficacies of caspofungin or micafungin catheter lock solutions on Candida albicans biofilm growth. J. Antimicrob. Chemother. 2008, 62, 153-155. [CrossRef] [PubMed]

36. Ko, K.S.; Lee, J.-Y.; Song, J.-H.; Peck, K.R. In vitro evaluation of antibiotic lock technique for the treatment of Candida albicans, C. glabrata, and C. tropicalis biofilms. J. Korean Med. Sci. 2010, 25, 1722-1726. [CrossRef] [PubMed]

37. Fiori, B.; Posteraro, B.; Torelli, R.; Tumbarello, M.; Perlin, D.S.; Fadda, G.; Sanguinetti, M. In vitro activities of anidulafungin and other antifungal agents against biofilms formed by clinical isolates of different Candida and Aspergillus species. Antimicrob. Agents Chemother. 2011, 55, 3031-3035. [CrossRef] [PubMed]

38. Öncü, S. In vitro effectiveness of antifungal lock solutions on catheters infected with Candida species. J. Infect. Chemother. 2011, 17, 634-639. [CrossRef] [PubMed]

39. Simitsopoulou, M.; Kyrpitzi, D.; Velegraki, A.; Walsh, T.J.; Roilides, E. Caspofungin at catheter lock concentrations eradicates mature biofilms of Candida lusitaniae and Candida guilliermondii. Antimicrob. Agents Chemother. 2014, 58, 4953-4956. [CrossRef] [PubMed]

40. Basas, J.; Morer, A.; Ratia, C.; Martín, M.T.; Del Pozo, J.L.; Gomis, X.; Rojo-Molinero, E.; Torrents, E.; Almirante, B.; Gavaldà, J. Efficacy of anidulafungin in the treatment of experimental Candida parapsilosis catheter infection using an antifungal-lock technique. J. Antimicrob. Chemother. 2016, 71, 2895-2901. [CrossRef] [PubMed]

41. Lown, L.; Peters, B.M.; Walraven, C.J.; Noverr, M.C.; Lee, S.A. An Optimized Lock Solution Containing Micafungin, Ethanol and Doxycycline Inhibits Candida albicans and Mixed C. albicans-Staphyloccoccus aureus Biofilms. PLoS ONE 2016, 11, e0159225. [CrossRef] [PubMed]

42. Tobudic, S.; Lassnigg, A.; Kratzer, C.; Graninger, W.; Presterl, E. Antifungal activity of amphotericin B, caspofungin and posaconazole on Candida albicans biofilms in intermediate and mature development phases. Mycoses 2010, 53, 208-214. [CrossRef] [PubMed]

43. Katragkou, A.; Chatzimoschou, A.; Simitsopoulou, M.; Dalakiouridou, M.; Diza-Mataftsi, E.; Tsantali, C.; Roilides, E. Differential activities of newer antifungal agents against Candida albicans and Candida parapsilosis biofilms. Antimicrob. Agents Chemother. 2008, 52, 357-360. [CrossRef] [PubMed]

44. Schinabeck, M.K.; Long, L.A.; Hossain, M.A.; Chandra, J.; Mukherjee, P.K.; Mohamed, S.; Ghannoum, M.A. Rabbit model of Candida albicans biofilm infection: Liposomal amphotericin B antifungal lock therapy. Antimicrob. Agents Chemother. 2004, 48, 1727-1732. [CrossRef] [PubMed]

45. Bailey, E.; Berry, N.; Cheesbrough, J.S. Antimicrobial lock therapy for catheter-related bacteraemia among patients on maintenance haemodialysis. J. Antimicrob. Chemother. 2002, 50, 615-617. [CrossRef] [PubMed]

46. Arnow, P.M.; Kushner, R. Malassezia furfur catheter infection cured with antibiotic lock therapy. Am. J. Med. 1991, 90, 128-130. [CrossRef]

47. Benoit, J.L.; Carandang, G.; Sitrin, M.; Arnow, P.M. Intraluminal antibiotic treatment of central venous catheter infections in patients receiving parenteral nutrition at home. Clin. Infect. Dis. 1995, 21, 1286-1288. [CrossRef] [PubMed]

48. Wu, C.-Y.; Lee, P.-I. Antibiotic-lock therapy and erythromycin for treatment of catheter-related Candida parapsilosis and Staphylococcus aureus infections. J. Antimicrob. Chemother. 2007, 60, 706-707. [CrossRef] [PubMed]

49. Viale, P.; Petrosillo, N.; Signorini, L.; Puoti, M.; Carosi, G. Should lock therapy always be avoided for central venous catheter-associated fungal bloodstream infections? Clin. Infect. Dis. 2001, 33, 1947-1948; author reply 1949-1951. [CrossRef] [PubMed]

50. Angel-Moreno, A.; Boronat, M.; Bolaños, M.; Carrillo, A.; González, S.; Pérez Arellano, J.L. Candida glabrata fungemia cured by antibiotic-lock therapy: case report and short review. J. Infect. 2005, 51, e85-e87. [CrossRef] [PubMed]

51. Shuford, J.A.; Rouse, M.S.; Piper, K.E.; Steckelberg, J.M.; Patel, R. Evaluation of caspofungin and amphotericin $B$ deoxycholate against Candida albicans biofilms in an experimental intravascular catheter infection model. J. Infect. Dis. 2006, 194, 710-713. [CrossRef] [PubMed]

52. Mukherjee, P.K.; Long, L.; Kim, H.G.; Ghannoum, M.A. Amphotericin B lipid complex is efficacious in the treatment of Candida albicans biofilms using a model of catheter-associated Candida biofilms. Int. J. Antimicrob. Agents 2009, 33, 149-153. [CrossRef] [PubMed]

53. Castagnola, E.; Marazzi, M.G.; Tacchella, A.; Giacchino, R. Broviac catheter-related candidemia. Pediatr. Infect. Dis. J. 2005, 24, 747. [CrossRef] [PubMed] 
54. Buckler, B.S.; Sams, R.N.; Goei, V.L.; Krishnan, K.R.; Bemis, M.J.; Parker, D.P.; Murray, D.L. Treatment of central venous catheter fungal infection using liposomal amphotericin-B lock therapy. Pediatr. Infect. Dis. J. 2008, 27, 762-764. [CrossRef] [PubMed]

55. Paul DiMondi, V.; Townsend, M.L.; Johnson, M.; Durkin, M. Antifungal catheter lock therapy for the management of a persistent Candida albicans bloodstream infection in an adult receiving hemodialysis. Pharmacotherapy 2014, 34, e120-e127. [CrossRef] [PubMed]

56. McGhee, W.; Michaels, M.G.; Martin, J.M.; Mazariegos, G.V.; Green, M. Antifungal Lock Therapy with Liposomal Amphotericin B: A Prospective Trial. J. Pediatr. Infect. Dis. Soc. 2016, 5, 80-84. [CrossRef] [PubMed]

57. Piersigilli, F.; Auriti, C.; Bersani, I.; Goffredo, B.; Bianco, G.; Savarese, I.; Dotta, A. Antifungal lock therapy with combined 70\% ethanol and micafungin in a critically ill infant. Pediatr. Infect. Dis. J. 2014, 33, 419-420. [CrossRef] [PubMed]

58. Lazzell, A.L.; Chaturvedi, A.K.; Pierce, C.G.; Prasad, D.; Uppuluri, P.; Lopez-Ribot, J.L. Treatment and prevention of Candida albicans biofilms with caspofungin in a novel central venous catheter murine model of candidiasis. J. Antimicrob. Chemother. 2009, 64, 567-570. [CrossRef] [PubMed]

59. Isgüder, R.; Ceylan, G.; Sandal, Ö.; Sarı, F.; Gülfidan, G.; Demirağ, B.; Ağın, H.; Devrim, İ. Reasons for failure of antifungal-lock technique with caspofungin: Need for higher concentrations. J. Ped. Emerg. Intensive Care Med. 2017, 4, 30-32. [CrossRef]

60. Ozdemir, H.; Karbuz, A.; Ciftçi, E.; Dinçaslan, H.U.; Ince, E.; Aysev, D.; Yavuz, G.; Doğru, U. Successful treatment of central venous catheter infection due to Candida lipolytica by caspofungin-lock therapy. Mycoses 2011, 54, e647-e649. [CrossRef] [PubMed]

61. Andes, D.; Nett, J.; Oschel, P.; Albrecht, R.; Marchillo, K.; Pitula, A. Development and characterization of an in vivo central venous catheter Candida albicans biofilm model. Infect. Immun. 2004, 72, 6023-6031. [CrossRef] [PubMed]

62. Bookstaver, P.B.; Rokas, K.E.E.; Norris, L.B.; Edwards, J.M.; Sherertz, R.J. Stability and compatibility of antimicrobial lock solutions. Am. J. Health Syst. Pharm. 2013, 70, 2185-2198. [CrossRef] [PubMed]

63. Raad, I.I.; Hachem, R.Y.; Hanna, H.A.; Fang, X.; Jiang, Y.; Dvorak, T.; Sherertz, R.J.; Kontoyiannis, D.P. Role of ethylene diamine tetra-acetic acid (EDTA) in catheter lock solutions: EDTA enhances the antifungal activity of amphotericin B lipid complex against Candida embedded in biofilm. Int. J. Antimicrob. Agents 2008, 32, 515-518. [CrossRef] [PubMed] 